\title{
National Archaeological Site Park Planning Based on Landscape Archaeology
}

\author{
Lian Jingsen*, Liao Muyun \\ Email address: \\ 1214450097@qq.com (Lian Jingsen) \\ ${ }^{*}$ Corresponding author
}

School of Architecture, Central Academy of Fine Arts, Beijing, Republic of China

\section{To cite this article:}

Lian Jingsen, Liao Muyun. National Archaeological Site Park Planning Based on Landscape Archaeology. American Journal of Civil Engineering. Vol. 9, No. 3, 2021, pp. 74-83. doi: 10.11648/j.ajce.20210903.13

Received: April 20, 2021; Accepted: May 19, 2021; Published: May 24, 2021

\begin{abstract}
National archaeological site parks are important for scientific protection and sustainable utilization of China's large ancient ruins. It is noteworthy that there is a lack of systematic analyses and dynamic strategies for the planning of archaeological sites parks, a lack of a comprehensive method for extracting earth surface information of archaeological sites, and especially a lack of post procedural research on how human beings transform the surrounding environment of the sites. The traditional research paradigm of archaeological site park planning based solely on archaeology or landscape architecture needs to be updated, as an interdisciplinary discipline, landscape archaeology has the research advantages of being more inclusive and restoring the original state of human land interaction between ancient human and ancient environment. This paper first explains the concept of landscape archaeology and the new vision of Chinese archaeological sites parks, and then, puts forward the lack of cultural connotation in spatial background, and the absence of dynamic thinking in temporal dimension through the analysis of existing domestic archaeological site park. And it is further explored from the "protection of authenticity ", "heritage cultural landscape reproduction", "protection and utilization", "dynamic monitoring" four levels. Finally, from the micro perspective, the paper puts forward a five-stage optimized framework of archaeological site park planning based on the perspective of landscape archaeology.
\end{abstract}

Keywords: Landscape Archaeology, National Archaeological Site Park, Planning Strategy, Protection and Utilization, Optimization

\section{Introduction}

Taking archaeological sites and their ambient space as the main objective of national archaeological research, it is of great significance in the protection and demonstration of national archaeological sites [1]. The construction of archaeological sites began with the Liangzhu consensus on the construction of archaeological site parks proposed during the Liangzhu Forum on the protection of large sites in 2009. To date, 36 archaeological site parks in China have been listed as national archaeological site parks [2]. The preliminary planning program of national archaeological site parks has been formed, and in 2013, the National Archaeological Site Park Planning Requirements and other normative documents (2018 development report) were published.

As a key link in the construction of Chinese archaeological site parks, the planning of archaeological site parks coordinates implementation of value protection, cultural service and ecological function, and ensures the feasibility of the construction of archaeological site parks from the aspects of research report, upper level planning, space design, exhibition and operation management [3]. The National Cultural Heritage Administration and the Chinese Academy of Cultural Heritage have proposed in the "Requirements for the Planning of National Archaeological Site Parks (Trial)", that the planning scheme of the site park shall be determined on the premise of accurately explaining the value of the site and evaluating the environmental conditions of the sites. [4] Shan Jixiang thinks that the planning of archaeological site parks should involve the protecting of the cultural ecology of the relics, and show the unique charm and value of the relics in the cultural space [5]. However, due to the lack of recognition and evaluation site protection and park construction and development from a broad spectrum view, most of the 
planning schemes of archaeological site parks are general and homogeneous, which will not provide effective guidance for the construction and development of archaeological site parks with unique charm of cultural heritages.

At present, the researches on the planning of archaeological site parks in China mainly focus on the qualitative planning of physical space, that is, the construction planning and overall management system framework of archaeological site parks [6]. Some scholars have begun to pay attention to the dynamic planning of archaeological site parks in terms of operation and management and land tenure. There is still a lack of researches on the technical methods and flexible non-material space planning strategies concerning both archaeological excavation and cultural display. Judging by the current situation, it is urgent to adopt further planning strategies that emphasize the dynamic, reciprocal and sustainable relationship between the physical space and cultural connotation of archaeological sites, so as to form a long-term mechanism with equal emphasis on the conservation and development of archaeological site parks After the 1980s, the study of landscape archaeology matured rapidly in both theory and methodology. It involves a variety of disciplinary fields [7], continuously expanding theoretical horizons and developing practical strategies, opening up a new path for the planning of Archaeological site parks that adapts to the development requirements of the new era. Based on this fact, the objectives of this study are as follows: 1) to discuss the concept and value of Landscape archaeology; 2) to discuss the current situation of domestic Archaeological Site Park planning combined with specific cases; 3) to review the application prospect of Landscape archaeology in Archaeological Park Planning; 4) to build an "optimized planning framework based on Landscape archaeology 1" supported by international cases and normative documents.

\section{The Concept of Landscape Archaeology and Its Application in the Planning of Archaeological Site Parks}

\subsection{Landscape Vision of Archaeology and the Background of Landscape Archaeology}

"Landscape" has been studied within the field of archaeology for a long time. However, there are distinct differences in the archaeologists' perspectives of landscape concept. Early Archaeological Studies on landscape have focused on the relationship between human and land, focusing on the dynamic interaction between landscape succession and human activities in a region, and the dynamic concept of landscape under archeological semantics has begun to take shape. In fact, among the researches of landscape architecture planning involving archaeology, most of them focus on the spatial analysis of environmental elements by settlement morphology archaeology, i.e. environmental analysis, a part of environmental archaeology. However, landscape archaeology is a comprehensive discipline exploring the spatial structure of earth's surface and human social practice throughout the history. Compared with environmental archaeology (Table 1), in addition to textual research on the characteristics of surface space and the changes of natural environment, landscape archaeology emphasizes human's understanding of the surrounding environment in the process of transforming nature [8].

Table 1. Conceptual distinction between landscape archaeology and environmental archaeology.

\begin{tabular}{llll}
\hline Contrast & & Environmental Archaeology & Landscape archaeology \\
\hline & Disciplinary Influences & Process Archaeology & Post procedural archaeology /Anthropogeography \\
& Entry Points & Natural Environment & Interaction between subjective perception and natural environment \\
& Working Methods & Spatial analysis & Spatial analysis and social relationship network analysis \\
& Construction mode & Bottom up & Top-down and bottom-up in parallel \\
Differences & Core issues & $\begin{array}{l}\text { The mechanical function of elements of } \\
\text { natural space on the land surface and }\end{array}$ & $\begin{array}{l}\text { The continuous dynamic transformation process caused by human } \\
\text { through exerting subjective initiative on the environment }\end{array}$ \\
& Time perspective & Time point and time period / event & Timeline / succession \\
& $\begin{array}{l}\text { Spatial perspective } \\
\text { Key interdisciplinary }\end{array}$ & "Point" or "multipoint" linear relationship & Regional linear and nonlinear linkage relationship \\
& disciplines & Geography, biology, history & Sociology, anthropology, ecology, art \\
& $\begin{array}{l}\text { Research objects } \\
\text { Applied technology }\end{array}$ & Natural environment elements and human social activities \\
& Integrated properties & Various cutting-edge science and technology, GIS, satellite remote sensing, etc \\
Similarities & Interdisciplinary and comprehensive emerging disciplines \\
\hline
\end{tabular}

The study of landscape archaeology is multidisciplinary, dynamic and regionally specific. First of all, researches related to the landscape archaeology involve history, archaeology, ecology, art, sociology, anthropology, geography and many other fields in natural and physical sciences, and humanities and social sciences. Therefore, landscape archaeology does not only revolve the archaeological methods, but to achieve the overall knowledge of a specific space through the integration of a variety of tangible and intangible elements in the site. Secondly, the heritages are not static and passive objects in the nature, since they reflect the subjective initiative of human in the process of transforming nature. From the perspective of time and space, with the changes of human understanding, the meaning and characteristics of landscape have also undergone continuous changes. Landscape archaeology emphasizes the interaction between human and environment instead of environment working as a decisive factor. Landscape is related to the social environment and spiritual essence of human beings. Landscape archaeology is to explore the dynamic interaction between the humanistic meaning of landscape and the natural 
environment [8]. Finally, compared with the traditional settlement archaeology, Landscape archaeology focuses more on the connection between social context and cultural connotation of different sites, because sites are the result of the synergy effect of nature and humanity, not linear geometric relationship. Therefore, Landscape archaeology plays key role in the excavation and textual researches of heritages in terms of the continuity and relevance of landscape.

\subsection{New Visions Brought to the Planning of National Archaeological Site Parks}

The interdisciplinary nature of landscape archaeology makes it possible to build bridges between archaeology and multiple disciplines (Figure 1). It is directly or indirectly related to the research genealogy from natural physical sciences to archaeology, and then to humanities and social sciences. Compared with other types of heritage parks, international archaeological site parks depend on broader vision of heritage protection and multidisciplinary collaborative research (Figure 2), which coincides with the idea that landscape archaeology is a kind of system built by a variety of theories and methods. Landscape archaeology will provide a new visions for the planning of national archaeological site parks, such as the comprehensive regional research based on field surveys, mapping, palynological analysis, soil detection and topographic exploration based on GIS technology [9], the contextualization of "living situations" of human societies [10-11], and methods to capture the public's perception of sites and landscape and add it to scientific opinions [10].
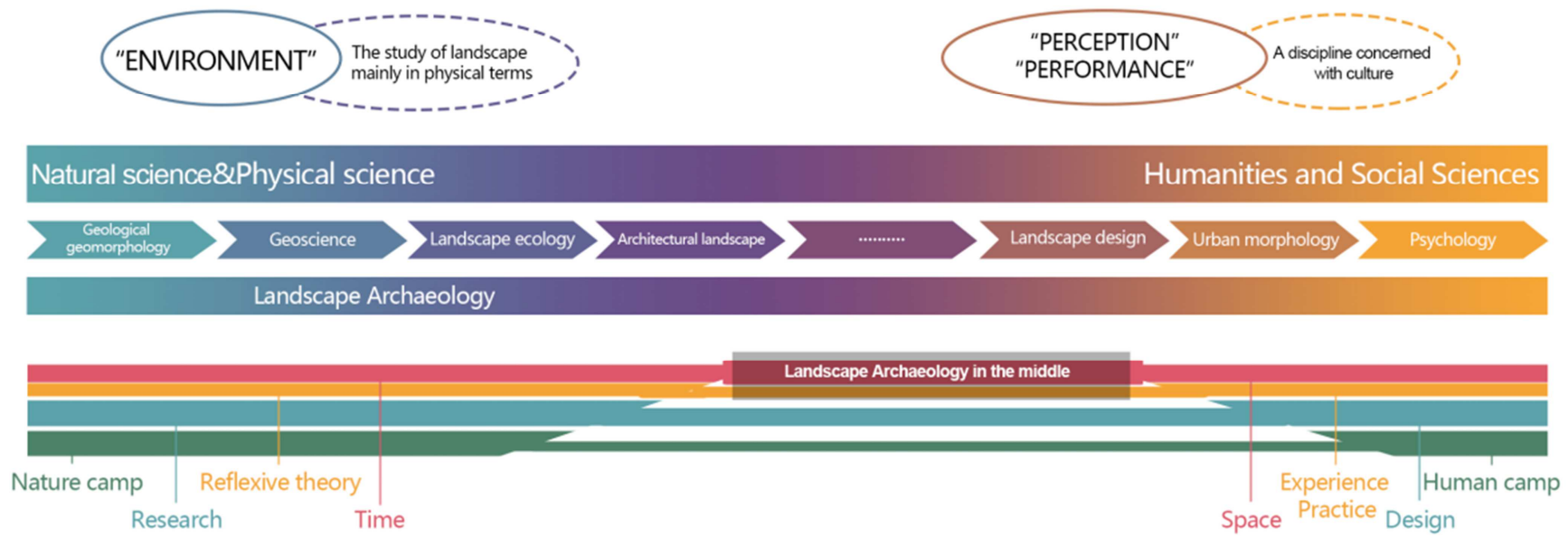

Figure 1. Multi-Disciplinary Application Spectrum of Landscape Archaeology.

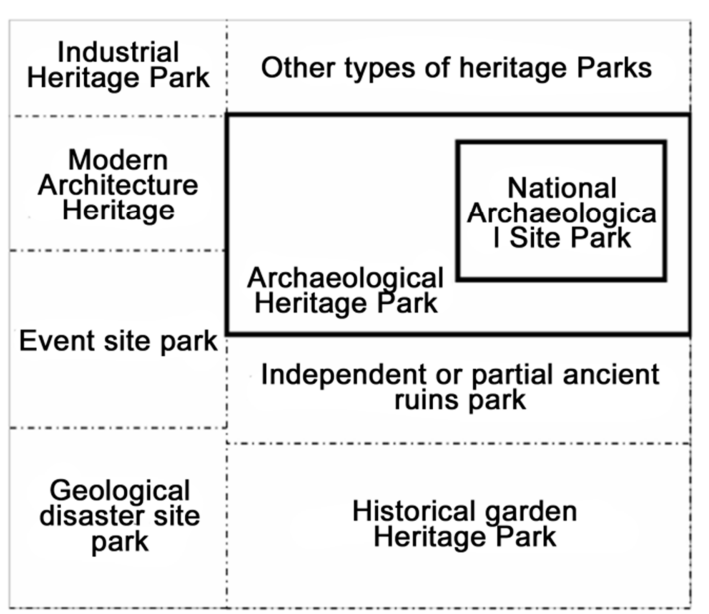

Figure 2. Classification of Heritage Park [11].

\section{Analysis of the Problems of National Archaeological Site Parks from the Perspective of Landscape Archaeology}

The planning of archaeological site parks is of great significance to the study, protection, utilization and management of heritages. Understanding the characteristics of archaeological park planning is conducive to solving the problems in the systematic application of landscape archaeology. Based on literature research and case study of archaeological site parks, the problems faced by archaeological site parks from the spatial and temporal aspects of landscape archaeology are: the lack of cultural connotations in different spatial backgrounds, and the lack of dynamic thinking in temporal dimension (Table 2).

Table 2. Analysis on the current situation of national archaeological site parks [12-17].

\begin{tabular}{|c|c|c|c|c|}
\hline \multirow{2}{*}{$\begin{array}{l}\text { Name of National } \\
\text { Archaeological Site } \\
\text { Park }\end{array}$} & \multicolumn{3}{|l|}{ Spatial dimension } & \multirow{2}{*}{$\begin{array}{l}\text { Temporal dimension } \\
\text { Lack of human and natural } \\
\text { dynamics }\end{array}$} \\
\hline & The Site Park & $\begin{array}{l}\text { Natural environment around } \\
\text { the site }\end{array}$ & $\begin{array}{l}\text { Planning the Red Line } \\
\text { Outer Space }\end{array}$ & \\
\hline $\begin{array}{l}\text { Old Summer Palace } \\
\text { (Yuan Ming Yuan) } \\
\text { National } \\
\text { Archaeological Site } \\
\text { Park }\end{array}$ & $\begin{array}{l}\text { Some sites are exaggerated and } \\
\text { deliberately processed to echo } \\
\text { historical scenes, without } \\
\text { accurately showing the } \\
\text { historical value of the heritage. }\end{array}$ & $\begin{array}{l}\text { The intervention of modern } \\
\text { garden design techniques in } \\
\text { some areas has disturbed the } \\
\text { natural form of the } \\
\text { mountainous water system. The }\end{array}$ & & \\
\hline
\end{tabular}




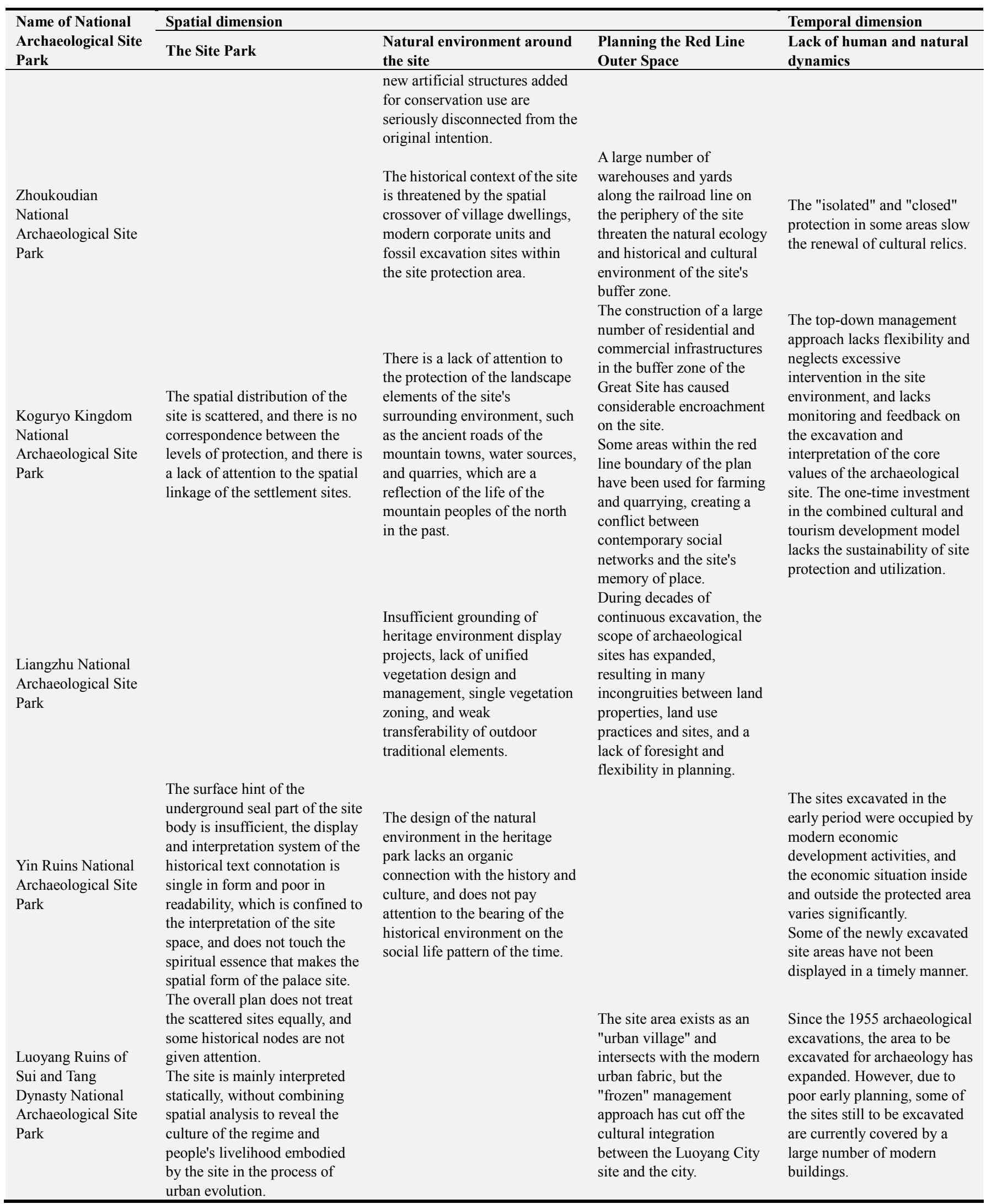

Note: Based on the National Archaeological Site Park Development Report released by the National Cultural Heritage Administration and the published planning scheme. 


\subsection{Lack of Humanistic Connotation in Spatial Dimension}

In spatial dimension, the lack of interpretation of the cultural value of a heritage can be found in three scales (scales in ascending order): the site, the surrounding space of the site, and the surrounding space beyond the boundary red line (Figure 3). Based on the "regional" analysis method of Landscape archaeology, three problems were spotted: 1) in the scale of the archaeological site, the cultural connotation of its core value is not fully presented. For example, in the site protection planning of the Mausoleum of the First Qin Emperor, the demonstration of the core value of the cultural heritage did not receive enough attention [12]. 2) The surrounding environment of the site has the tendency of "artificial" and "stylized" design, which weakens the restoration of the historical social scenery, the visibility of historical information, and the characteristics of "Archaeology" and "heritage". For example, the intervention of modern landscape design techniques in some areas of Old Summer Palace (Yuan Ming Yuan) National Archaeological Site Park seriously disjointed the original intention of classical gardens with artificial construction [13]. 3) The main problem is the contradiction between the complex land use of the peripheral space of the site and the overall urban development strategy which is out of line with the planning of the archaeological site parks. The "isolated ", "dotted" and " fragmented" plans have threatened the integrity and authenticity of the natural environment and social environment of the sites. For example, in recent years, villagers built houses in the buffer zone around the Zhongdu of Yuan Dynasty National Archaeological Site Park. The destruction of natural and social environment caused by house and random grazing shows the social contradiction of "protection restricts development, development affects protection" in archaeological site planning. At present, with the development of archaeological technology and the increase of protected area and strictness under the policy of cultural strategy, the contradiction of archaeological site park from the perspective of space has been intensified in the short term, and the lack of cultural connotations in different spatial scales of archaeological site park is more unbalanced. In the long-term perspective, it is urgent for landscape archaeology studies to interpret the overall humanistic value of archaeological site park planning base on "regional linear and non-linear linkage relationship".

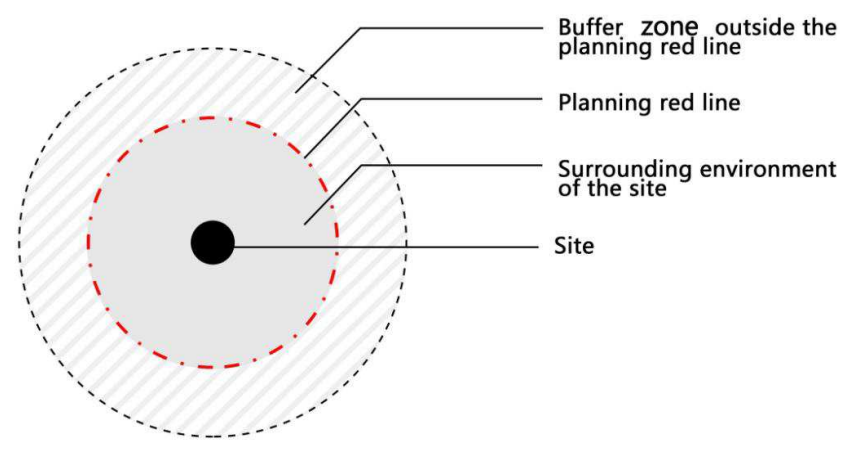

Figure 3. Three Scales in Spatial Dimension.

\subsection{The Absence of Dynamic Thinking in Temporal Dimension}

From the perspective of "time succession" of landscape archaeology, "dynamic thinking" is reflected in the planning of archaeological site park, a cycled process from the natural environment archaeology to the summary of human connotation, and then back to the re-exploration, re-interpretation and re-learning of the value of archaeological sites. Large-scale construction based solely on archaeological information will not only hinder the follow-up archaeological work, but also cause irreversible damages to archaeological sites. In general, the reason for the lack of dynamic thinking in the temporal dimension lies in the fact that most construction projects need to be completed and put into use in a short period of time due to the one-time investment of funds and the interests of all parties in the planning process of archaeological heritage park [14]. Especially for large-scale archaeological site parks, there is too much archaeological historical information to be displayed in a short time, so it needs to be revealed by stages and regions, instead of building a museum that shows the core value of the archaeological site park with early stage archaeological excavation results. For example, the construction of Liangzhu museum was completed as early as 1992, but the main body of Liangzhu ancient city was found in 2007, after 15 years of archaeology work, which reflects the problem of putting the cart before the horse in the planning of archaeological site park. In addition, the uncertainty of archaeological protection of the Neolithic and Neolithic large-scale settlement sites, large-scale ancient city sites, ancient emperor's Mausoleum and various large-scale tombs [15] are more prominent. Some scholars only focus on the evaluation and discussion of whether the site tourism has produced the expected benefits [16], instead of whether the development of archaeological site park is sustainable, and how to provide the optimized planning schemes under the dynamic vision [17].

\section{Review on the Application of Landscape Archaeology in the Planning of National Archaeological Site Parks}

Can the planning of archaeological site park effectively solve the space-time problems of different cases? Based on the comparison of Landscape archaeology literature and some archaeological sites park planning texts and case studies, it was found that, due to the lack of landscape archaeology intervention in the existing archaeological sites park, some implementation schemes and master plans of archaeological sites park were superficial. There are vague planning policies, restricted heritage protection and regeneration approaches, unbalanced protection and utilization methods, and a lack of targeted control measures for dynamic development. Application of landscape archaeology in archaeological site park planning will be beneficial in the following four aspects. 


\subsection{Protection of Authenticity: Apply Right Criteria for Archaeological Site Parks}

Since the promulgation of the Venice Charter in 1964, the principle of "authenticity" has attracted much attention in the field of cultural heritage. In 1977, the guidelines for the implementation of the World Heritage Convention listed the principle of "authenticity" as the basic idea of world heritage protection. Immediately after the establishment of the world heritage protection mechanism, "authenticity" was a classic concept, focusing on "material remains". Since the promulgation of Nara document on authenticity in 1992, the connotations of authenticity has become more comprehensive, more flexible and more specific. On the basis of material remains, the concept of authenticity has been extended to landscape and social scopes. In the current National Archaeological Site Park planning requirements (Trial), the theme "interpretation" only concerns the site space, and there is no emphasis on the social form beyond the site. Archaeological site parks are an important part of the world heritage. It is not enough to protect the authenticity of the entity. The planning of archaeological site parks emphasizes the protection of the authenticity of historical scenes, including the interpretation of the cultural connotation of the site, the maintenance of the ecological environment, the structure of geographical features and other aspects of landscape science. Landscape archaeology emphasizes the interpretation of the multiple connotations of "authenticity" on the stage of site investigation; this provides precision and effectiveness for the classification, archaeological revelation and interpretation of different protected areas in the planning stage of archaeological site parks.

\subsection{Coming from Ancient times -- Protection, Restoration and Reappearance of Cultural Landscape of Heritages}

Cultural landscape is the focus in the process of protection and restoration of archaeological site parks. Revealing part of the park for the display and interpretation of historical information is often based on cultural landscape. At present, many archaeological sites parks tend to pay attention to one thing and lose the other, such as relying too much on digital approach and social networks to present the cultural landscape of the sites, or offering a glimpse by making a large number of simple "historical miniature landscapes" in the actual planning process. Cultural landscape is a comprehensive concept, and landscape archaeology studies regard the internal and external aspects of the site and emphasize on the subjective initiative of modern people rather than the copying of historical stereotypes. Viewers' memory needs to be recalled through visiting the site and watching the scene, rather than reading the in-depth research results [13]. This provides an opportunity for the maximum exploration of the connotation of cultural landscape, and more emphasis is placed on finding an innovative fitting point between the public participation in actual space and the multi-sensory experience of virtual historical scenes.

\subsection{Equal Emphasis on Protection and Utilization: Balance Ancient and Modern Cultures}

A comprehensive and effective mode for the protection and utilization of Archaeological site parks has been formed after years of practice. Still, there is a restriction mechanism between "protection" and "utilization" [18]. It is worth exploring scientific and appropriate ways to address the contradiction between the two. Some archaeological site parks put "protection" in the first place and fail to promote the visibility of the heritage, while some parks put too much emphasis on "utilization" using modern landscape design techniques, which weakens the depth of heritage resources and the ability to create "memories".

Landscape archaeology provides a new trade-off mechanism to solve this problem. The concept of "landscape" focuses on the dynamic relationship between spatial place and social situation. It not only integrates and sorts out earth surface structure, environmental factors and other information of archaeological sites with the help of relevant research methods of geography and ecology, but also learns from the knowledge framework of sociology and anthropology to improve the time connotation and humanism of archaeological sites in the aspects of "cultural memory" and "social identity", "social order" and "social transformation". This characteristic of Landscape archaeology will aid the planning of archaeological site parks in accurate capture, storage, management, analysis, display and evaluation of historical data, so as to establish a complete, systematic and comprehensive information system [19].

\subsection{Provide Theoretical Support for Real-time Dynamic Monitoring of Site Protection and Utilization}

As a dynamic space, an archaeological site park is not only a park for public participation, but also a place for archaeological excavation. Compared with the traditional archaeological model, landscape archaeology pays more attention to the "time line" development, and regards the archaeological site park as a "Process stage" for archaeology studies that inspires the subjective initiative of archaeologists. Therefore, in the planning stage, it is required not only to compartmentalize the space according to the degree of public participation, but also to monitor the degree of social intervention in different areas in real time, and strictly control the intervention or damage by tourists on the plots with potential archaeological value, so as to ensure a flexible space for planning and designing, and the sustainability of both park archaeological research and tourism development of both.

\section{Optimized Framework for Planning National Archaeological Heritage Park Based on Landscape Archaeology}

Based on the analysis of space-time problems of archaeological site parks with landscape archaeology approaches and the review of landscape archaeology 
application in archaeological site parks, this study was conducted to construct an optimized the planning framework for archaeological site parks (Figure 4). Starting from the empirical study of archaeological site parks, and following instructional documents, this study explored the formation mechanism and key points of space-time problems in the planning process to put forward a series of planning optimization strategies, such as "social regeneration" and "reversible" juxtaposition of ancient and modern sites. The optimized planning framework of archaeological site parks consists of five links: information and data collection, information arrangement, planning, disposal implementation system and dynamic monitoring intervention evaluation.

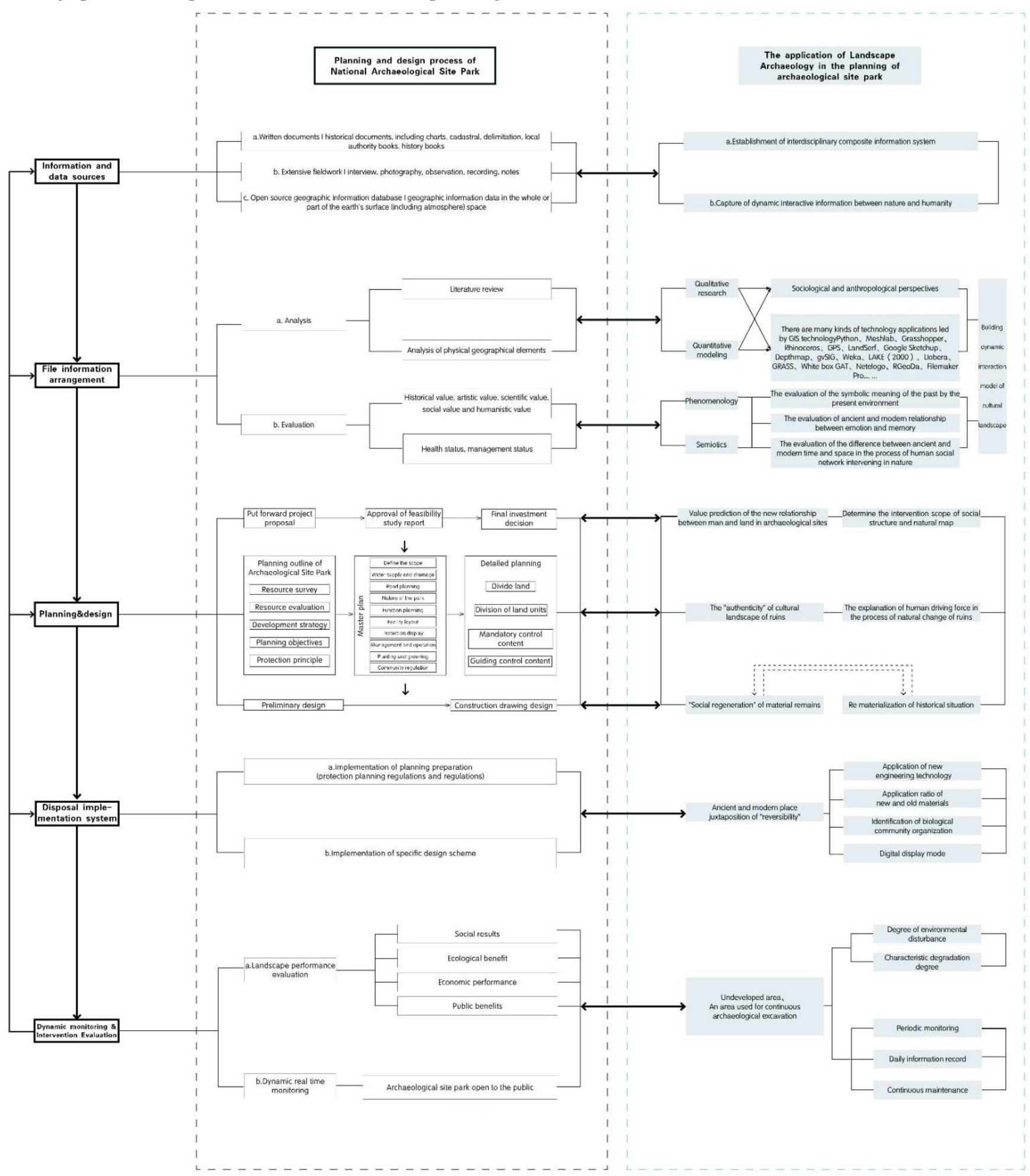

Figure 4. Research framework of National Archaeological Site Park Planning Based on Landscape archaeology. 


\subsection{Information and Data Collection}

This link is about the processing of the information of the archaeological remains and the capture of the spatial pattern of the environment. First, based on the collected documents, field survey and geographic spatial information data, etc., the interdisciplinary and composite information system was established. Then, based on the spatial analysis and GIS statistical analysis, the dynamic interaction information between nature and humanity was captured. For example, the location of the core city of ancient civilization was judged by the surrounding environment and landform of the site, the distribution of river direction and the relic of ancient river, and the chronological history of the ruins group [20].

\subsection{Information Arrangement}

This link is the pre-analysis of the planning of archaeological site park. First, the qualitative research and quantitative modeling were combined to form the information analysis in the view of Landscape archaeology. The information analysis from the perspective of landscape archaeology is the diversified processing of literature review and natural geographic information. The key is the fully open perspective, for example, the reason for the decline of settlement civilization in Parpa Valley in Peru was not natural disasters such as extreme weather. after archaeological investigation of ancient terraces and irrigation system, the social conflicts among land development, population density and water source were found in the upstream and downstream rivers [21]; through the analysis of church customs and traditional farming methods used by believers, a typological model of the types of vegetation and water sources was built for the bathhouse heritage [22]; the dependence of the civilization on different production methods of fishing, hunting and farming was analyzed according to the distribution results of the standard deviation of a certain settlement group combined with the topography and surface remains. [23] This link includes the evaluation of symbolic significance of the present environment and the past based on phenomenology and semiotics, the evaluation of the relationship between emotion and memory, and the evaluation of the difference between ancient and modern time and space in the process of human social network intervention in the natural succession.

\subsection{Planning Optimization}

Based on the principle of large site archaeology, this link is to determine the core value orientation of park planning. Combining with the diverse theories, methods and practical experience of landscape archaeology, the study puts forward an optimized strategy of archaeological site park planning. First, the value of the new relationship between human and land of archaeological sites was predicted, and the goal was to determine the intervention scope of social structure and natural layout. Then, in the specific outline, it was proposed to reveal the "authenticity" of cultural landscape and to explain the humanistic driving force in the process of natural change in the planning stage. Finally, the "social regeneration" of material remains and "re-materialization" of historical situation was achieved at the design level. For example, in Moundville archaeological park of the United States terrain and vegetation were rearranged according to archaeological documents and GIS elevation data, and "soil piles" and other surface natural elements were repaired to display the social class and tribal culture of the original residents [24]; in the Flag Fen archaeological site park of the UK, wetland flora organization and farm restoration structures were combined to recreate The process of ancient population transforming the natural environment of the marsh [25].

\subsection{Disposal Implementation System}

This link is an important part of the long-term planning and management of the archaeological site parks. The "reversibility" of ancient and modern placement is the principle of the same position proposed by Landscape archaeology for planning and implementation of specific design scheme. It includes the application of new engineering technology, the proportion of new and new materials used, the identification of biological community organization, and the digital display mode.

\subsection{Dynamic Monitoring \& Intervention Assessment}

This link is a lasting topic in long-term sustainability assessment and benefit control of the site parks. Landscape archaeology proposes sustainable measures to distinguish undeveloped areas and areas used for sustainable archaeological excavation from the target of environmental interference and degradation degree of features, and to carry out periodic monitoring, daily information recording and continuous maintenance.

The research framework of National Archaeological Site Park Planning Based on Landscape archaeology is proposed in this study. It aims to explore the solutions of archaeological site park problems base on multi-disciplinary analysis, and improve the effectiveness of archaeological site park planning as a whole, which provide supplement and expansion to the theories and methods of archaeological site park planning in China.

\section{Conclusion}

Based on literature review and case study, this paper explains the concept and value of landscape archaeology, specifically, its interdisciplinary, regional and dynamic characteristics, which are in accordance with the need of integrity, authenticity, scientific approaches and culture in the protection and utilization of archaeological site parks. From the perspective of landscape archaeology, some of the existing archaeological site parks in China have not been fully interpreted in the three scales in spatial dimension, such as the disjunction of the natural environment around the site and the original cultural image of the site, and the conflict between the site and the urban context outside the planning scope. The 
flexibility to the planning schedule is rather weak. A sustainable system of protection and utilization has not been formed, and the dynamic interaction between human and natural environment has not been addressed. Landscape archaeology provides many possibilities for solving these problems, which is embodied in the emphasis of humanism in the extended concept of "authenticity" in planning stage, the attention to site memory in the recreation of heritage cultural landscape, the establishment of the balance mechanism between protection and utilization, and the theoretical support for dynamic monitoring of archaeological and display of sites. In view of the specific application of landscape archaeology, a composite information system will be beneficial for the diverse processing of archaeological information in planning stage, highlighting the multidisciplinary feature of landscape archaeology, and establishing a mechanism of intervention evaluation and dynamic monitoring feedback to ensure the sustainability of archaeological site parks.

Archaeology is the starting point of site protection, but the current approaches, traditional settlement form archaeology or environmental archaeology, are not connected closely with site protection. Archaeological research is usually conducted in the earlier working stage, to provide a lot of basic data for the later planning. But the planning is subjective, design method is used to improve the environmental quality of the site, which draws less attention in the early research on environmental archaeology. Therefore, in the whole work process, much basic historical information provided by the early archaeological stages cannot be used efficiently and accurately to guide the planning. The focus on comprehensive concept of "landscape" in landscape archaeology brings the relationship between human and land forward in the planning stage. In addition to the objective historical data such as nature and human society, the attention is paid to the long process of reconstruction of the site environment from the perspective of "human". In line with the original intention of restoring natural environment, this will achieve the accurate matching of data acquisition and output, and optimize the planning mode of archaeological site park.

\section{References}

[1] State Administration of cultural relics. Guidelines for the establishment, operation and management of national archaeological sites Park (Trial) [EB / OL]. (2018) [2018-04-11] http://www.sach.gov.cn/art/2018/1/30/art_1036_146797.html.

[2] State Administration of cultural relics. Development report of National Archaeological Heritage Park [EB / OL]. [April 20, 2019] http://www.gov.cn/fuwu/2018-10/12/content_ five million three hundred and twenty-nine thousand seven hundred and ninety-eight $\mathrm{htm}$. National Cultural Heritage Administration. National Archaeological Site Park Development Report [EB/OL]. [2019-04-20]. http://www.gov.cn/fuwu/2018-10/12/

[3] Wang Xinwen, Fu Xiaomeng, Zhang Pei. Research progress and trend of archaeological sites Park [J]. Chinese garden, 2019, 35 (07): 93-96.
[4] State Administration of cultural relics. Requirements for the planning of national archaeological sites Park (Trial) [EB / OL] (2009)

[2018-04-15] http://www.sach.gov.cn/art/2012/12/31/art_1036_93843.html.

[5] Shan Jixiang. Exploration and practice of large archaeological sites Park [J]. Chinese cultural relics research, 2010 (01): 2-12.

[6] Zhao Wenbin. Research on planning mode of National Archaeological Site Park [D]. Beijing Forestry University, 2012.

[7] Zhang Hai. Landscape archaeology: theory, method and practice [J]. Southern cultural relics, 2010 (04): 8-17.

[8] Jiao Tianlong. Introduction to Landscape archaeology [n]. China Heritage daily, 2010-6-29.

[9] G. Nicholas, J. Hollowell. Series Editors' Foreword. [C]. Handbook of landscape archaeology. Britain: Routledge., 2016. 123-130.

[10] Graham Fairclough. Look the other way-from a branch of archaeology to a root of landscape studies [C]. Landscape archaeology between Art and Science. Holland: Amsterdam University Press, 2012. 471-483.

[11] Wang Luyan. Research on the principles and methods of greening national archaeological sites Park [D]. Xi'an University of architecture and technology, 2013.

[12] Feng Shumei, Yuan Yue, Zhu Xingying, Zhang Yifan, Zhu Yuanping. Study on tourism development validity and Countermeasures of Liangzhu site [J]. Jiangnan forum, 2020 (12): 36-38.

[13] Zhao Xia. Analysis on the characteristics of Liangzhu site protection and utilization $[\mathrm{J}]$. International cultural management, 2016 (00): 163-174.

[14] Qian Guifeng. Peking Man Site in Zhoukoudian [J]. World heritage, 2015 (z1): 32-35.

[15] Chen Ruyi, sun Bingying, Yang Hua. Research on the protection and development strategy of luonanlifang site in Luoyang City in Sui and Tang Dynasties [a] IFLA Asia Pacific region, Chinese society of landscape architecture, Shanghai greening and city appearance administration. 2012 IFLA Asia Pacific Conference and 2012 annual meeting of Chinese society of Landscape Architecture (Volume I) [C]. IFLA Asia Pacific region, Chinese society of landscape architecture, Shanghai greening and city appearance administration: Chinese society of Landscape Architecture, 2012: 4.

[16] Tong Shishu. Research on the protection of Gaogouli mountain city site in Liaoning Province [D]. Shenyang Jianzhu University, 2012.

[17] Hu Xing, Jiang Ying Chao. Study on the protection and sustainable development of Peking Man Site in Zhoukoudian [J]. Beijing Social Sciences, 2010 (03): 17-23.

[18] Zhuang Youbo, Yang Rui. Study on zoning planning of Huangshan Scenic Area [J]. Chinese garden, 2006 (12): 32-36.

[19] Guo Xiaotong, Yang Chen, Han Feng. Digital recording and protection innovation of cultural landscape heritage $[\mathrm{J}]$. Chinese garden, 2020, 36 (11): 84-89.

[20] V. Strang. The social construction of water. [C]. Handbook of landscape archaeology. Britain: Routledge., 2016. 123-130. 
[21] R. Hesse, J. Baade. A qualitative model for the effect of upstream land use on downstream water availability in a western Andean valley, southern Peru [C]. Landscape archaeology between art and science: From a multi-to an interdisciplinary approach. Holland: Amsterdam University Press, 2012. 241-247.

[22] M. Kampa, I. Ispikoudis. Cultural forces in the creation of landscapes of south-eastern Rhodope: Evolution of the Byzantine monastic landscape [C]. Landscape archaeology between art and science: From a multi-to an interdisciplinary approach. Holland: Amsterdam University Press, 2012. 71-79.
[23] Xu Yongjie. Settlement form of iron age in Heilongjiang Province [J]. Frontier archaeological research, 2003 (00): 211-222.

[24] J. H. Blitz. Moundville [M]. University of Alabama Press: America, 2008. 98-105.

[25] F. Pryor. The Flag Fen Basin: archaeology and environment of a Fenland landscape. [M]. English Heritage: Britain, 2013. 351-381. 